\title{
Forecast of Circulation Processes and Propagation of Oil Pollution in the Eastern Black Sea Based on the Regional Complex Model
}

\section{A.A. Kordzadze, D.I. Demetrashvili}

\author{
Nodia Institute of Geophysics \\ of the Javakhishvili Tbilisi State University, Tbilisi, Georgia \\ e-mail: akordzadze@yahoo.com
}

\begin{abstract}
Regional system for the eastern Black Sea dynamic state short-term forecasting (the liquid boundary passes along $39.08{ }^{\circ} \mathrm{E}$ ) is expanded by including the model of oil pollution spreading. The model is based on solution of a two-dimensional transfer-diffusion equation for non-conservative impurity using the two-cycle splitting method with respect to geometrical variables. Non-stationary current field necessary for calculation of oil pollution forecast is obtained by the regional model of the Black Sea dynamics, which is a core of the regional forecasting system. The regional model of sea dynamics is nested in the basin-scale model of Marine Hydrophysical Institute (MHI, Sevastopol). All the input data required for the calculation of current and thermohaline fields are taken from the MHI via the Internet in near-operational mode. Input parameters are the following: 3D initial fields of current velocity components, temperature and salinity; 2D fields of the same values on the liquid boundary; 2D meteorological fields of heat flows, precipitation, evaporation and the tangential wind stress at the sea surface. Alongside with a forecast of currents, temperature and salinity fields, the proposed system, if necessary, permits to forecast oil pollution spread for 3 days with $1 \mathrm{~km}$ spatial resolution. The numerical experiments performed for the cases of various locations of a hypothetic pollution source occurring under actual circulation modes show a significant role of dynamic processes in formation of some features of spatial-temporal pollution distribution.
\end{abstract}

Keywords: current field, numerical model, splitting method, diffusion, oil patch.

DOI: 10.22449/1573-160X-2015-1-3-14

(C) 2015, A.A. Kordzadze, D.I. Demetrashvili

(C) 2015, Physical Oceanography

Introduction. The cooperation of Marine Hydrophysical Institute (MHI) and Institute of Geophysics of the Javakhishvili Tbilisi State University within the framework of European scientific projects has resulted in the development of regional system for the eastern Black Sea dynamic state short-term forecasting (the liquid boundary passes along $39.08^{\circ} \mathrm{E}$ ). The given system is a part of the Black Sea basin-scale nowcasting/forecasting system [1 - 6]. A general scheme of regional system functioning and some results of dynamic characteristic forecast in the eastern part of the Black Sea basin are described in [7 - 11]. The main component of the system is a regional model of the Black Sea dynamics (RM-IG) obtained by adaptation of the Black Sea baroclinic model developed at Institute of Geophysics $[12,13]$ to the eastern part of the sea with the simultaneous resolving power increase from $5 \mathrm{~km}$ to $1 \mathrm{~km}$. A computational grid of regional model is nested in the grid of the Black Sea dynamics model (developed at MHI) with $5 \mathrm{~km}$ spatial step [3]. The system provides 3 days forecast of currents, temperature, salinity and density fields in the mentioned area.

The developed dynamic processes regional forecasting system will be a basis for the development of complex system for the Black Sea state forecasting and modeling. In future, this system will allow to forecast not only the changes of 
dynamic processes, but also, if necessary, the areas of oil and other pollutants spreading; to reveal the location of pollution source according to the known concentrations of pollutants in the upper sea layer, etc.

In recent decades, an intensive pollution of several regions of the World Ocean with oil products and other highly toxic substances of anthropogenic origin takes place. In this regard, a special place is held by inland water bodies, which are particularly sensitive to anthropogenic loads due to their low water exchange with the World Ocean. Primarily, the aforementioned fact may be referred to the Black Sea where the pollution progresses significantly. It is well known that the Black Sea is one of the most contaminated basins of the World Ocean due to anthropogenic impact and hydrological features [14 - 17]. For the Black Sea, as well as for other seas, oil and petroleum products are the most common and dangerous pollutants. According to the data given in [14], the annual quantity of oil emissions into the Black Sea (for 2003) was 110000 tons. In one of the documents prepared by the Parliamentary Assembly of the Council of Europe [17], where the contribution of large rivers to the Black Sea pollution is quantified, it is mentioned that only the Danube annually carries out into the sea 50000 tons of oil products. Nowadays the Black Sea plays a role of corridor for oil transportation from the East to the West, and in the coming years this transportation is expected to increase. This fact creates a sufficient potential threat of even greater ecosystem pollution with oil products.

The development of oil pollution forecasting methods is one of the urgent problems of contemporary applied oceanography [18, 19]. A reliable operational forecast of distribution and concentration areas of pollutants in case of accidental oil spills will allow to optimize the effectiveness of performing measures in order to bring down to the minimum the possible negative consequences caused by oil pollution.

The basic mechanisms for concentration variability and distribution of oil pollution in the marine environment are described in detail in [14, 20 - 22]. In addition to advective transfer and turbulent diffusion, in the first days after the spillage oil concentrations are also affected by evaporation, emulsification and dispergation processes. A sufficient number of works (e.g. [14, 23 - 38]) is dedicated to the modeling of oil patch transfer in the Black Sea and in other seas. We will briefly mention some of them. In [14] an integrated model of the Black Sea water circulation and oil patch drift on the basis of the random walking particles approach, which allows tracking the motion of single particles (sum total of them makes an oil slick). Circulation parameters were derived from DiaCAST model [39] adapted for the Black Sea. The model from [14] was also used for the Caspian Sea [24 - 26], but the fields of currents and turbulence were reproduced by means of POM model [40] adapted for the Caspian Sea.

An advanced model of oil pollution drift [27], which is an additional module to the operational model of ocean circulation, was developed at Danish Meteorological Institute. Turbulent motion is described by Monte Carlo method. This model is used for the North and Baltic Seas and allows forecasting not only the oil slick spread on the sea surface, but also the amount of oil immersed in the lower layers.

Three-dimensional oil pollution model MOTHY [28 - 32] connected to the model of ocean circulation was developed by French meteorological service 
Météo-France. MOTHY model is used for the Aegean Sea, the Mediterranean Sea and for other regions of the World Ocean. The adaptation of this model to the Bourgas Bay [33] was performed by Bulgarian national meteorological service. Nowadays MOTHY is a component of a system of operational marine forecasts in Bulgaria and it can be used in case of emergencies.

In [34] a system of the weather, wind-induced waves and sea current simulation, in which the model of oil slick drift is included, was developed. MM5 model [41] is used for operational weather forecasting in the Black Sea region, for the simulation of wave-induced waves - WAVEWATCH III [42], and the Black Sea hydrodynamics is calculated by means of POM model [40]. The simulation system is implemented for the north-western shelf of the Black Sea and for estuaries of the Dnieper and the Bug.

In $[37,38]$ the process of oil (spilled on the sea surface in quantities) propagation all over the Black Sea was simulated on the basis of a transferdiffusion equation for non-conservative impurity.

In this paper, the eastern Black Sea dynamic state short-term regional forecasting system is expanded by including the model of oil pollution spreading $[37,38]$. Some results of numerical experiments on the forecasting of regional water circulation and oil slick drift for the cases of hypothetical pollution source different location in the conditions of real circulation modes are represented.

Module of oil patch transfer. After the oil slick formation affected by gravitational forces, viscosity and sea surface tension, its subsequent behavior can be described by transfer-diffusion equation for non-conservative impurity. Oil slick begins transferring and changes the size and configuration under the effect of hydrodynamic factors - advection and turbulent diffusion. Simultaneously, the oil submerged into the lower sea layers, is exposed to physical and biochemical transformation. As far as our goal is a calculation of 3 days pollution spread forecasting, among the physical and biochemical factors the most important is the oil evaporation, whose intensity depends on the oil fractional structure and external conditions - temperature, wind velocity and also the area of oil spread. Oil is a mixture of hydrocarbon compounds, and after the spill volatile components with low boiling point rapidly evaporate. Therefore, evaporation intensity depends on the oil type. According to [22], on average during the time period from several hours to 24 hours from one to two thirds of the total mass of the oil spill disappear due to evaporation.

In two-dimensional domain $\Omega$ with $S$ boundary the transfer-diffusion equation for non-conservative impurity written in divergent form is considered

$$
\frac{\partial \varphi}{\partial t}+\frac{\partial u \varphi}{\partial x}+\frac{\partial v \varphi}{\partial y}+\sigma \varphi=\frac{\partial}{\partial x} \mu_{\varphi} \frac{\partial \varphi}{\partial x}+\frac{\partial}{\partial y} \mu_{\varphi} \frac{\partial \varphi}{\partial y}+f,
$$

with the following boundary and initial conditions:

$$
\begin{gathered}
a\left(\mu_{\varphi} \frac{\partial \varphi}{\partial n}-\beta \varphi\right)+b Q=0 \quad \text { to } S, \\
\varphi=\varphi^{0} \quad \text { when } t=0 .
\end{gathered}
$$

PHYSICAL OCEANOGRAPHY NO. 1 (2015) 
Here it is assumed that the horizontal $u$ and $v$ components of current along $x$ and $y$ axes satisfy the continuity equation:

$$
\frac{\partial u}{\partial x}+\frac{\partial v}{\partial y}=0
$$

Other notations are the following: $\varphi$ - volume concentration of substance; $\mu_{\varphi}-$ turbulent diffusion coefficient; $n$ - external normal to the boundary $S$; $\sigma=\ln 2 / T_{0}-$ non-conservative parameter, which describes the concentration change due to evaporation and other factors; $T_{0}$ is a time interval during which the initial concentration of pollution decreases twofold; $f$ generally describes a spatio-temporal power distribution of $Q$ source, which can be represented by $\delta$-function in a particular case of a point source:

$$
f=Q \delta\left(x-x_{0}\right) \delta\left(y-y_{0}\right),
$$

here $x_{0}$ and $y_{0}$ - coordinates of the source. In the boundary condition (2) $a$ and $b-$ the coefficients taking on the values 1 or $0 ; \beta$-parameter that characterizes the interaction of the pollutant with the boundary. The diffusion coefficient was calculated by the formula [43]

$$
\mu_{\varphi}=\gamma \Delta x \Delta y \sqrt{2\left(\frac{\partial u}{\partial x}\right)^{2}+\left(\frac{\partial u}{\partial y}+\frac{\partial v}{\partial x}\right)^{2}+2\left(\frac{\partial v}{\partial y}\right)^{2}},
$$

where $\Delta x$ and $\Delta y$ - horizontal grid steps, and $\gamma$ - some constant.

The problem (1) - (3) was solved numerically using the dicyclic splitting method by $x$ and $y$ coordinates, and for time approximation the Crank - Nicolson scheme was applied [44].

Hydrodynamic module. Nonstationary current field necessary for calculation of oil pollution forecast is obtained by the RM-IG model, which is the main component of regional forecasting system. All the input data required for the calculation of current and thermohaline fields are taken from the MHI model via the Internet in operational mode [7 - 10]. Input parameters are the following: threedimensional initial fields of current velocity components, temperature and salinity; two-dimensional fields of the same values on the liquid boundary; two-dimensional meteorological fields of heat flows, precipitation, evaporation and the tangential wind stress at the sea surface. The fields on the liquid border are the prognostic values obtained by the model of the Black Sea dynamics of Marine Hydrophysical Institute, and meteorological fields - prognostic values calculated by regional model of atmosphere dynamics $A L A D I N$.

The basis of RM-IG model is a complete system of hydrodynamics equation written in a rectangular Cartesian coordinate system. The equation system is solved using a dicyclic method of splitting into physical processes, vertical coordinate planes and lines [45 -47]. The following basic factors are considered in the model: 
1) wind effect and the flows of heat and salt; 2) bottom relief and configuration of the sea basin; 3) shortwave radiation absorption by the upper layer of the sea; 4) spatiotemporal variation of viscosity and diffusion coefficients; 5) streamflow of Georgia's rivers.

Input parameters. The model of oil pollution propagation is included into the regional forecasting system by which, in case of emergency situation, it is possible to calculate 3 days forecast for oil concentration and areas of oil propagation with $1 \mathrm{~km}$ spacing. For this purpose the coordinates of pollution source location, quantity of oil spilled on the sea surface and sill duration are set to the system. The fields of currents are calculated by RM-IG model.

In the models of dynamics and oil pollution a grid having $215 \times 347$ points on horizons is used. In the dynamics model 32 calculated levels on a vertical with non-uniform vertical steps are taken (minimum step - $2 \mathrm{~m}$ at the surface, maximum $-100 \mathrm{~m}$ in the deep layers below $200 \mathrm{~m}$ ). Time step of both models $-0.5 \mathrm{hrs}$. In specific numerical experiments on oil propagation modeling it was specified: $a=1$, $b=0, \beta=0, \gamma=0.1$.

Considering the fact, that on the first day after the spill the evaporation is rather sufficient, it was taken that nonconservative parameter $\sigma=1.6 \cdot 10^{-5} \mathrm{c}^{-1}$ under $t \leq 12 \mathrm{hrs}$, which corresponds to $50 \%$ oil mass loss for $1 / 2$ day. As the main goal of the work is the study of dynamic factors effect on the oil spill spreading, the assumed values of nonconservative parameters averagely characterize the decomposition rate and don't belong to particular type of oil.

Modeling and forecasting of regional dynamic processes in the Black Sea eastern part. The comparison of results of hydrophysical fields forecast, performed by means of our regional model, with observation data (including satellite data and results of MHI model) showed that real dynamic processes in eastern part of the sea are reproduced well by the regional system $[2,7]$. Besides, it became clear that the high resolution of numerical model is an essential factor for identifying the coastal submesoscale eddy formations with $5-12 \mathrm{~km}$ diameter. According to our data such formations often occur in a narrow zone along the Caucasus coast [7 - 10]. It should be noticed that the existence of such eddies near the Caucasus coast is proved by hydrological studies performed in 2007 - 2008 in Gelendzhik area [48]. Submesoscale eddies are also identified in other coastal areas of the Black Sea [49, 50].

In [51] a scheme of the Black Sea surface circulation was built on the basis of hydrographical studies, carried out before 1990. In [52] this scheme was slightly modified by addition of some coastal eddies. The main features of the Black Sea waters general circulation, including coastal mesoscale eddy formations, are shown at both diagrams. In [51] the circulation in the modeled eastern part of the basin is represented by Batumi Anticyclonic Eddy (BAE), and in [52] a relatively small eddy, which had been formed in the waters near Sukhumi (Sukhumi Eddy). The results of circulation and thermohaline fields calculation, accumulated in the last $3-4$ years, show that easternmost part of the Black Sea is a dynamically active region. In this part of the Black Sea, in addition to BAE and Sukhumi Eddy, cyclonic and anticyclonic eddy formations of different scales continuously form throughout the year $[10,11]$. 


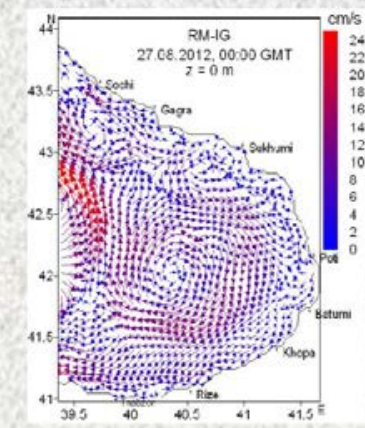

a

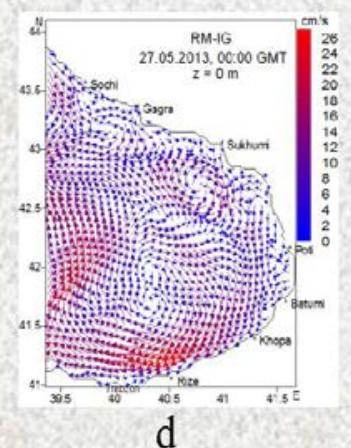

d

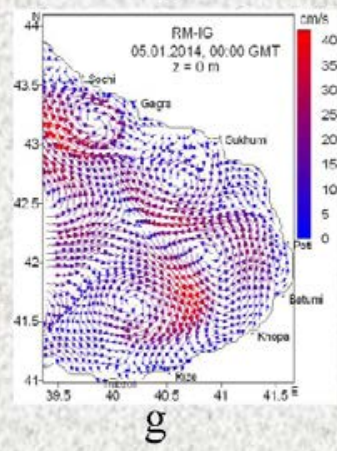

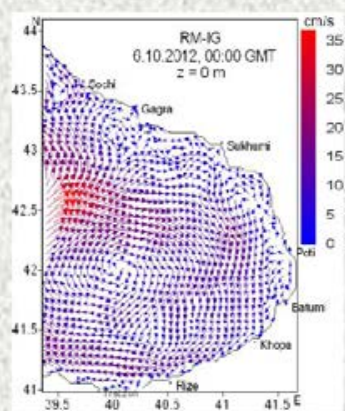

b

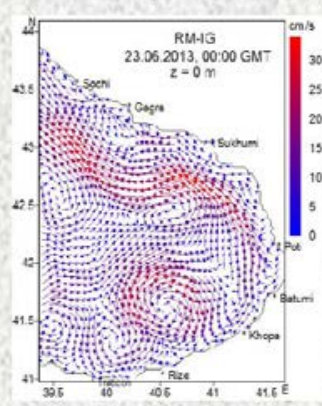

e

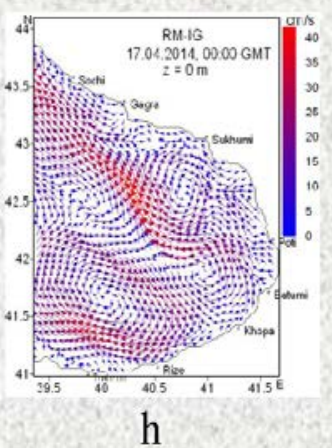

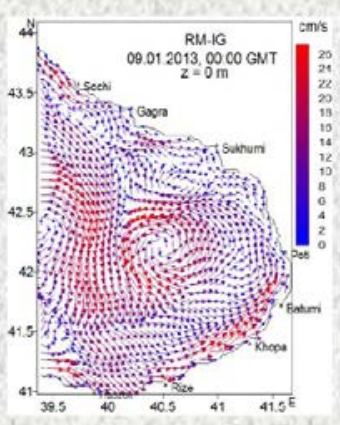

C

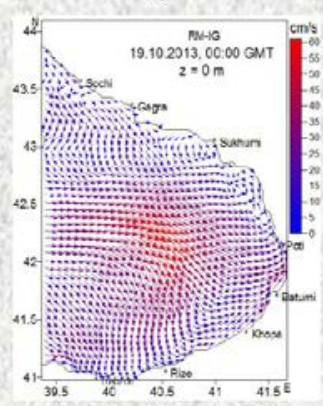

f

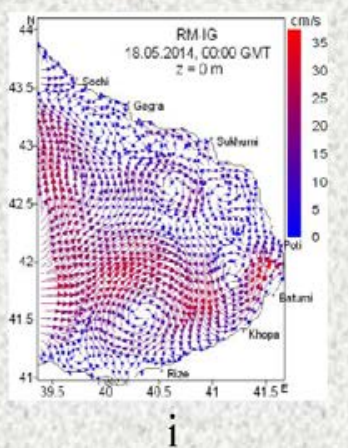

Fig. 1. Prognostic fields of surface currents in the Black Sea eastern part in 2012 - 2014: $a$ - August 27, 2012, b - October 6, 2012, c - January 5, 2013, $d$ - May 27, 2013, $e$ - June 23, 2013, $f$ - October 19, 2013, $g$ - January 5, 2014, $h$ - April 17, 2014, $i$ - May 18, 2014.

In Fig. 1 some results of surface circulation evolution calculations on the basis of the regional forecasting system are represented to illustrate the mentioned processes. In order not to overburden the article with figures, some calculated fields only for 2012 - 2014, which, in our opinion, give some idea of interannual and annual variability of dynamic processes in the considering region of the Black Sea, were represented here. The fact that the dynamic structure of the sea upper layer is to some extent different in warm (April - October) and cold (November March) seasons is a general pattern. Thus, for example, approximately from March in the south-western part of the considering eastern waters BAE, which in future may become more intense and occupy large territory in this part of the sea, begins to form (Fig. 1, $a, b, c, d$ ). BAE exists during almost the entire warm season and is characterized by varying intensity. In most cases it is the main element of regional 
circulation. This eddy is quite stable and it covers $300-400 \mathrm{~m}$ vertically. In different years BAE reaches its maximum intensity in different months. For example, in 2012 BAE reaches its maximum size (with approximately 160 $180 \mathrm{~km}$ diameter) in October (Fig. 1, b), whereas in 2010 and 2011 - in summer.

During a maximum development phase in BAE a specific salinity regime is formed: in the central part of the eddy the salinity sufficiently decreases and its peripheral current promotes the penetration of more saline open sea waters into the easternmost sea part [7]. In September - November BAE gradually slackens and transforms into the current with several vorticities. In the cold period of year a dominant eddy formation is practically absent (Fig. 1, $c, g$ ) and circulation is characterized by several cyclonic and anticyclonic eddies with $\sim 40-60 \mathrm{~km}$ diameter. Also we should mention an anticyclonic eddy, which is often formed in the water area near Sukhumi (Fig. $1 d, g-i$ ). This eddy can be observed in any month, but mostly it is formed in warm season. Strong winds have smoothing effect at the surface current of the sea and promote the disappearance of eddy formations (Fig. 1, $f$ ). Sea current velocities affected by such wind increase up to $\sim 60-70 \mathrm{~cm} / \mathrm{s}$ and in some cases they can reach $100 \mathrm{~cm} / \mathrm{s}$.

Modeling and forecasting of oil patch transfer. Numerical experiments were performed to determine the effect of circulation regime and location of oil spill point on the pattern of oil patch transfer. In the given experiments an emergency oil emission in 50 tons quantity occurred during 2 hrs. Taking into account the fact that admissible concentration limit usually makes up $0.05 \mathrm{mg} / \mathrm{l}$, all concentrations less than $0,001 \mathrm{mg} / \mathrm{l}$ had been taken as equal to 0 .

In Fig. 2 the forecasting calculation results for current and oil slick transfer on the surface of the Black Sea for September 25 - 28, 2011 (00:00 GMT) are represented. In the first numerical experiment the oil spill point with $157 \Delta x$ and $142 \Delta y$ coordinated was located at the anticyclonic eddy area, closer to its center (about $45 \mathrm{~km}$ from Poti). In the second numerical experiment (Fig. 2, $f-h$ ) the oil spill point was displaced $20 \mathrm{~km}$ closer to the coast of Georgia and the coordinates of the point were $177 \Delta x$ and $142 \Delta y$. For the prognostic period under review a specific dynamic mode has formed: in the most part of waters there were formed two eddies with $\sim 60-70 \mathrm{~km}$ diameters, their centers were located in the southwestern part and approximately in the middle of the eastern part of these waters. Moreover, along the Caucasus and Turkish coast occurred a narrow zone where a substantial nonstationary process of unstable alongshore submesoscale eddies generation and dissipation had been observed. In both cases the oil path moves to the South due to anticyclonic eddy formation effect (Fig. 2). At the same time oil patches expand due to diffusion effect and oil concentrations gradually decrease due to the expansion of oil slicks and physical-chemical factors, which are taken into account in the model by specifying the nonconservative parameter. From Fig. 2, $e-h$ it is obvious that the oil patch takes the shape of a horseshoe gradually widening while transferring. Analysis of the figure allows us to conclude that a sufficient inhomogeneity of the velocity field at the part of water area covered with oil patch noticeably affects a deformation pattern of this patch.

Under this circulation regime and accidental spill location, considered in the numerical experiments, the oil patch raises the land at some distance. But there is no danger of pollution for the waters off the Georgia coast because the anticyclonic 
eddy (that during the considered prognostic time period undergoing a nonstationary restructuring) is located at some distance from the coast. Evidently, the processes of unsteady submesoscale eddy formation development in the narrow coastal zone prevent the approximation of the eastern branch of the eddy to the coasts of Georgia and, correspondingly, the oil pollution of coastal waters.

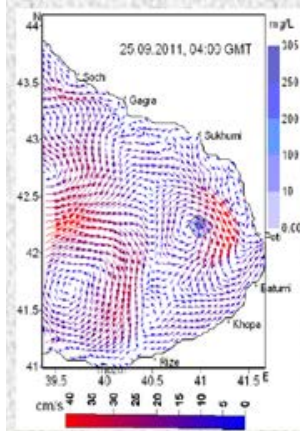

a

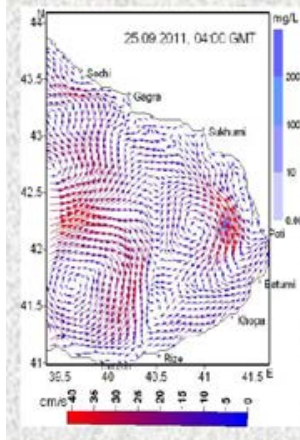

e

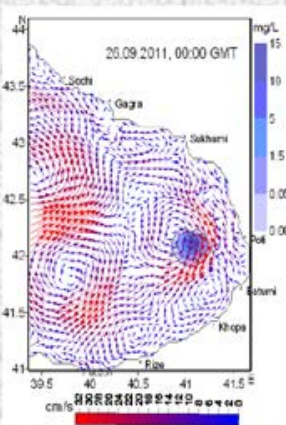

b

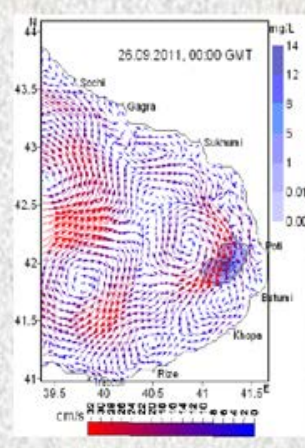

f

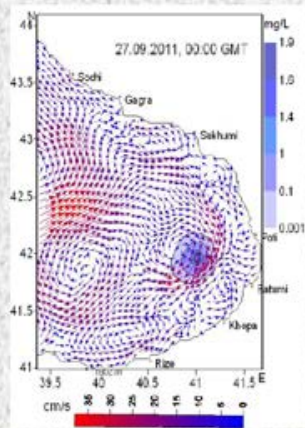

C

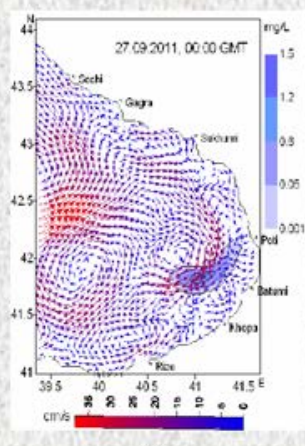

g

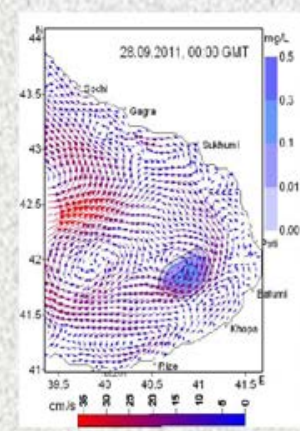

d

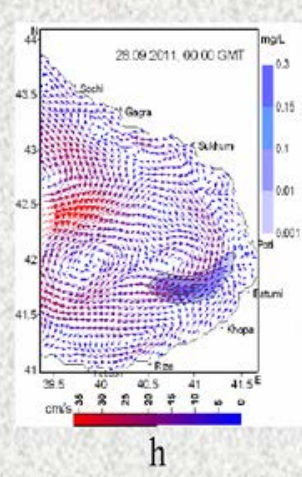

Fig. 2. Calculated surface currents and modeling oil patch in the indicated moments of time after the hypothetical accidental spill at the points with $\Delta x, 142 \Delta y(a, b, c, d)$ and $177 \Delta x, 142 \Delta y(e, f, g, h)$ coordinates (prognostic interval - September 25 - 28, 2011, 00:00 GMT)

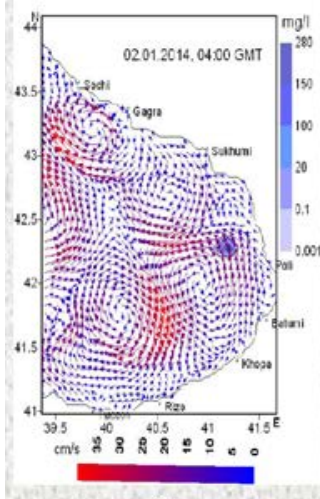

a

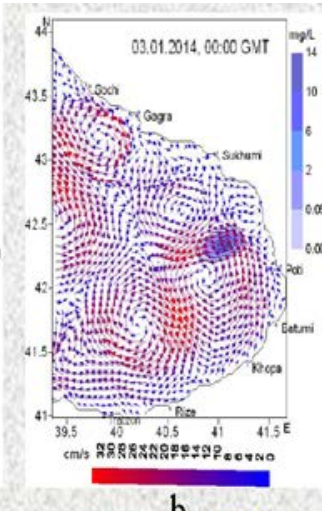

b

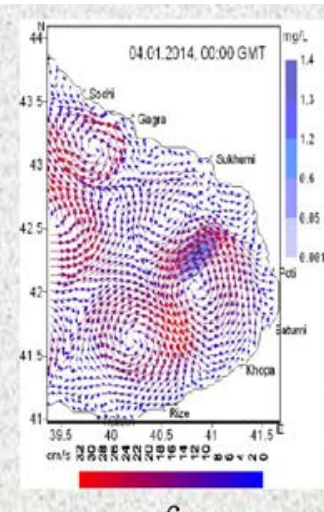

C

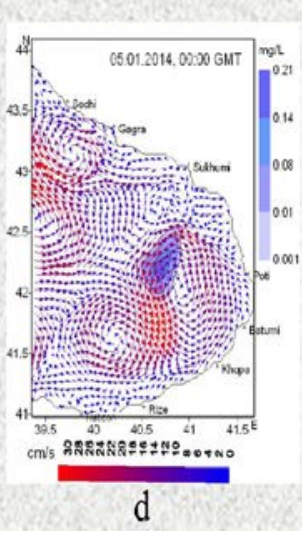

Fig. 3. Calculated surface currents and modeling oil patch in the indicated moments of time after the hypothetical accidental spill at the points with $177 \Delta x$ and $142 \Delta y(a, b, c, d)$ coordinates (prognostic interval - January 2 - 5, 2014, 00:00 GMT) 
In the other numerical experiment the location of oil spill point was the same as in the second numerical experiment (177 $\Delta x, 142 \Delta y$ ) but the dynamical structure was different (corresponding to the prognostic interval January $2-5$, 2014, 00:00 GMT). In Fig. 3 the calculated surface current and oil pollution at different moments after the accidental spill are represented. This figure clearly indicates that in the given case the oil patch behavior corresponds to circulation pattern and oil pollution bear off from the coasts of Georgia.

Additional numerical experiments revealed the following fact: when the oil spill occurs in the center of some eddy structure, eddy captures this oil pollution and there is no displacement of oil patch center, the patch expands under effect of diffusion, concentrations decrease.

Conclusion. The proposed Black Sea dynamic state regional short-term forecasting system in case of accidental spill permits to forecast oil pollution spread in the eastern Black Sea with $1 \mathrm{~km}$ spatial resolution alongside with a forecast of water circulation and thermohaline fields. Our approach to representation of oil slick drift on the sea surface is based on solution of twodimensional transfer-diffusion equation for non-conservative impurity using a real non-stationary field of currents calculated in a hydrodynamic block of regional system. In this connection, a spatio-temporal change of turbulence field is considered explicitly, and oil concentration decrease due to evaporation and other physicochemical factors is considered implicitly by setting a corresponding nonconservative parameter.

The analysis of calculation results of hydrophysical process forecast permits to conclude that dynamical processes developing in the considered part of sea basin are characterized by sufficient annual and interannual variability, which manifests itself in continuous generation and evolution of cyclonic and anticyclonic of eddy structures, from submesoscale alongshore eddies with $\sim 5 \mathrm{~km}$ diameter to gyres with $~ 100 \mathrm{~km}$ diameter.

Numerical experiments on oil pollution propagation modeling have shown that water circulation regime and location of oil spill point largely predetermine a pattern of oil patch transfer.

Further improvement of oil patch transferring model is associated with an explicit consideration of several physicochemical factors including the generalization for 3-D, which will allow us to consider the processes of sedimentation and dispersion vertically.

Acknowledgements. The studies presented in this paper were performed within the framework of a grant from Shota Rustaveli National Science Foundation (contract No. 30/07).

\section{REFERENCES}

1. Korotaev, G.K., Cordoneanu, E. \& Dorofeyev, V.L. [et al.], 2006, "Near-operational Black Sea nowcasting/forecasting system”, European Operational Oceanography: Present and Future, $4^{\text {th }}$ EuroGOOS Conference, 6-9 June 2005, Brest, France, pp. 269-275. 
2. Kubryakov, A.I., Grigoriev, A.V. \& Kordzadze, A. A. [et al.], 2006, “Nowcasting/Forecasting subsystem of the circulation in the Black Sea nearshore regions", European Operational Oceanography: Present and Future, $4^{\text {th }}$ EuroGOOS Conference, 6-9 June 2005, Brest, France, pp. 605-610.

3. Korotaev, G.K., Oguz, T. \& Dorofeyev, V.L. [et al.], 2011, "Development of Black Sea nowcasting and forecasting system”, Ocean Science, no. 7, pp. 629-649. doi: 10.5194/os-7629-2011, www.ocean-sci.net/7/629/2011/.

4. Kubryakov, A.I., Korotaev, G.K. \& Dorofeev, V.L. [et al.], 2012, "Black Sea Coastal forecasting systems”, Ocean Science, no. 8, pp. 183-196, doi: 10.5194/os-8-183-2012, www.ocean-sci.net/8/183/2012/.

5. Grigoriev, A.V., Zatsepin, A.G., 2011, "Verifikatsiya chislennoy modeli dinamiki vod rossiyskoy zony Chernogo morya po dannym distantsionnykh $i$ kontaktnykh nablyudeniy [Validation of numerical model of waters dynamics of the Black Sea (Russian zone) according to the in situ and remote data]", Ekologicheskaya bezopasnost' pribrezhnoy $i$ shel'fovoy zon i kompleksnoe ispol'zovanie resursov shel'fa, vol. 2, iss. 25, pp.147-160 (in Russian).

6. Grigoriev, A.V., Zatsepin, A.G., 2013, "Numerical modeling of water dynamics of Russian zone of the Black Sea within the framework of operational oceanography tasks", J. Georgian Geophys. Soc., no. 16b, pp. 138-157.

7. Kordzadze, A. A, Demetrashvili, D. I., 2011, “Operational forecast of hydrophysical fields in the Georgian Black Sea coastal zone within the ECOOP”, Ocean Science, no. 7, pp. 793-803, doi:10.5194/os-7-793-2011, www.ocean-sci.net/7/793/2011/.

8. Kordzadze, A.A., Demetrashvili, D.I., 2011, “Regional'naya operativnaya sistema prognoza sostoyaniya vostochnoy chasti Chernogo morey [Regional operational forecasting system of the easternmost Black Sea state]", Ekologicheskaya bezopasnost' pribrezhnoy i shel'fovoy zon i kompleksnoe ispol'zovanie resursov shel'fa, vol. 2 iss. 25, pp.136-146 (in Russian).

9. Kordzadze, A.A., Demetrashvili, D.I., 2012, "Coastal forecasting system for the easternmost part of the Black Sea”, Turkish Journal of Fisheries and Aquatic Science, no. 12, pp. 471-477, doi:10.4194/1303-2712-v12_2_38, www.trjfas.org.

10. Kordzadze, A.A., Demetrashvili, D.I., 2013, “Kratkosrochnyy prognoz gidrofizicheskikh poley $v$ vostochnoy chasti Chernogo morya [Short-range forecast of hydrophysical fields in the eastern part of the Black Sea]”, Ivestiya RAN, Fizika atmosfery i okeana, vol. 49, no. 6 , pp. 733-745 (in Russian).

11. Kordzadze, A.A., Demetrashvili, D.I., 2013, "Dynamical processes developed in the easternmost part of the Black Sea in warm period for 2010-2013”, J. Georgian Geophys. Soc., no. 16b, pp. 3-12.

12. Kordzadze, A.A., Demetrashvili, D.I. \& Surmava, A.A., 2004, “O reaktsii gidrologicheskogo rezhima Chernogo morya na izmenchivost' atmosfernykh protsessov [About reaction of hydrological regime of the Black Sea on variability of atmospheric processes]", Ekologicheskaya bezopasnost' pribrezhnoy i shel'fovoy zon i kompleksnoe ispol'zovanie resursov shel'fa, iss. 10, pp. 265-277 (in Russian).

13. Kordzadze, A.A., Demetrashvili, D.I., Surmava, A.A., 2008, "Chislennoe modelirovanie gidrofizicheskikh poley Chernogo morya $v$ usloviyakh cheredovaniya atmosfernykh tsirkulyatsionnykh protsessov [Numerical modeling of hydrophysical fields of the Black Sea in conditions of alternation of atmospherin citculation processes]", Ivestiya RAN, Fizika atmosfery i oceana, vol. 44, no. 2, pp. 227-238 (in Russian).

14. Korotenko, K.A., Dietrich, D.E. \& Bowman, M.J., 2003, “Modelirovanie tsirkulyatsii $i$ perenos neftyanykh pyaten $v$ Chernom more [Modeling circulation and oil spill transport in the Black Sea]”, Okeanologia, vol. 43, no. 3, pp. 367-378 (in Russian).

15. Korotaev G.K., Eremeev V.N., 2006, "Vvedenie v operativnuyu okeanografiyu Chernogo morya [Introduction to the Black Sea operative oceanography]”, Sevastopol, ECOSIGidrofizika, 382 p. (in Russian). 
16. Gubanov, E.P., Ievleva, M.N., 2006, "Neftyanoe zagryaznenie Chernogo morya i ego vliyanie na ekosictemu [Oil pollution of the Black Sea and its influence on ecosystem]", 16 p., http://www.ceemar.org/dspace/bitstream/11099/1132/1/article-13.pdf.

17. Mironescu, L., 2008, "The fight against harm to the environment in the Black Sea", Parliamentary Assembly Recommendation 1837, Doc.11632.

18. Lebedev, C.A., 2009, "Otsenka fonovogo zagryazneniya nefteproduktami CHernogo i Kaspiyskogo morey s ispol'zovaniem dannykh distantsionnogo zondirovaniya i model'nykh raschetov [Evaluation of oil pollution of the Black and Caspian seas using remote sensing data and model calculations]”, http://www.mkgtu.ru/docs/KONF_SEM/lebedev.pdf (in Russian).

19. "Oil spill accident in the Kerch strait in November 2007”, 2011, Eds. Korshenko A., Ilyin Y., Velikova V. Commision on the Protection of the Black Sea Against Pollution. Moscow, Nauka, 284 p.

20. Zhurbas, V. M., 1978, "Osnovnye mekhanizmy rasprostraneniya nefti $v$ more [The basic mechanisms of the spread of oil in the sea]”, Mekhanika zhidkosti i gaza, Moscow, VINITI, vol. 12, pp. 144-159 (in Russian).

21. Himiya okeana, vol. 1, Ed. by Bordovskiy, O.K. and Ivanenkov B.N., 1979, Moscow, Nauka, 518 p. (in Russian).

22. Vragov, A.B., 2002, "Metody obnaruzheniya, otsenki i likvidatsii avariynykh razlivov nefti [Methods for detection, assessment, and oil spill response]”, Novosibirskiy gosuniversitet, 224 p. (in Russian).

23. Ozmidov, P.V., 1986, “Diffuziya primesey v okeane”, Leningrad, Gidrometeoizdat, 280 p. (in Russian).

24. Korotenko, K.A., Mamedov, R.M. \& Mooers, C.N. K. 2001, "Prediction of the Dispersal of Oil Transport in the Caspian Sea Resulting from a Continuous Release”, Spill Science and Technology Bulletin, vol. 6, no. 5/6, pp. 323-339.

25. Korotenko, K.A., Mamedov, R.M. 2001, "Modeling of oil slick transport processes in coastal zone of the Caspian Sea”, Oceanology, 41. pp. 37-48.

26. Korotenko, K.A., Mamedov, R.M. \& Mooers, C.N.K. 2001, "Prediction of the transport and dispersal of oil in the south Caspian Sea resulting from Blowouts", Environmental Fluid Mechanics, vol. 1, no. 4, pp. 383-414.

27. Christiansen, Bettina M. 2003, "3D Oil drift and fate forecast at DMI”, Technical Report no. 03-36., Denmark, Danish Meteorological Institute.

28. Daniel, P., 1997,” Forecasting oil spill drift at Meteo-France “, Proceed. of the 1997 Intern. Oil Spill Conference. American Petrolium Institute, Washington, D. C., pp. 990-993.

29. Daniel, P., 1995, "Numerical simulation of the Aegean Sea oil spill”, Proceed. of the 1995 Intern. Oil Spill Conference. American Petrolium Institute, Washington, D. C., pp. 894-896, http://www.meteorologie.eu.org/mothy/references/iosc1995.pdf.

30. Daniel, P., Kortchev, G. \& Mungov, G., 1998, "Forecasting oil spill drift in the Black Sea”, Proceed. of oil spills in the Mediterranean and Black Sea regions. MEDOSC, University of Manchester, UK, P.D011-8.

31. Daniel, P., Poitevin, J. \& Tiercelin, C. [et al.], 1998, "Forecasting accidental marine pollution drift: the French operational plan, oil and hydrocarbon spills, modelling, analysis, and control”, Computational Mechanics Publications, pp. 43-52.

32. Daniel, P., Gilbert, T. \& Hackett, B. [et al.], 2008, “Operational metocean products and services in support of marine pollution emergency response operations”, Proceed. of the 2008 Intern. Oil Spill Conference. American Petrolium Institute, Washington D. C.

33. Galabov, V., 2011, “Oil spill drift operational forecasts for Bulgarian coastal area and numerical study of potential oil pollution in the bay of Burgas”, In: Abstracts $20113^{\text {rd }} \mathrm{Bi}$ annual BS Scientific Conference and UP-GRADE BS-SCENE Project joint Conference, Odessa, Ukraine. 
34. Brovchenko, I., Kuschan, A. \& Maderich, V. [et al.], 2002, "The modeling system for simulation of the oil spills in the Black Sea”, In: Proc. 2002, $3^{\text {rd }}$ EuroGOOS Conference, Athens/Greece.

35. Reed, M., Johansen, O. \& Brandvik, P.J. [et al.], 1999, “Oil spill modelling toward the close of the $20^{\text {th }}$ century: overview of the state of the art”, Spill Science and Tech. Bull, pp. 3-16.

36. Shou-Dong Wang, Yong-Ming Shen, \& Ya-Kun Guo [et al.], 2008, "Three-dimensional numerical simulation for transport of oil spills in seas”, Ocean Engineering, no. 35, pp. 503510 .

37. Kordzadze, A., Demetrashvili, D., 2000, "Numerical modeling of distribution of the oil pollution in the Black Sea”, J. Georgian Geophys. Soc., no. 5b, pp. 12-20.

38. Kordzadze, A., Demetrashvili, D. \& Surmava, A.A., 2005, “A numerical study of spreading of the oil pollution in the natural environment", Environmental ecology and life safety, no. 2, pp. 77-84.

39. Dietrich, D.E., Lin, C.A., \& Mestas-Nunez, A. [et al.] 1997, “A high resolution numerical study of Gulf of Mexico fronts and eddies”, Meteorol. Atmos. Phys., no. 64, pp. 187-201.

40. Blumberg, A.F., Mellor, G.L., 1987, “A description of a three-dimensional coastal ocean circulation model”, In: Three-Dimensional Coastal Ocean Models, American Geophysical Union, Washington, no. 4, pp. 1-16.

41. Grell, G., Dudhia, A.J. \& Stauffer, D.R., 1994, “A description of the fifth-generation Penn State/NCAR mesoscale model (MM5)”, NCAR Technical Note, NCAR/TN-398+STR.

42. Tolman, H.L., 1999, "User manual and system documentation of WAVEWATCH-III version 1.18”, NOAA/NWS/NCEP/OMB Technical Note 166.

43. Zilitinkevich, S.S., Monin, A.S., 1971, “Turbulentnost' v dinamicheskikh modelyakh atmosfery”, Leningrad, Nauka, 44 p. (in Russian).

44. Marchuk, G.I., 1982, "Matematicheskoe modelirovanie v probleme okruzhayushchej sredy”, Moscow, Nauka, 319 p. (in Russian).

45. Marchuk, G.I., 1967, “Chislennye metody v prognoze pogody”, Leningrad, Gidrometeoizdat, 356 p. (in Russian).

46. Marchuk, G.I., 1974, “Chislennoe reshenie zadach dinamiki atmosfery i okeana”, Leningrad, Gidrometeoizdat, 303 p. (in Russian).

47. Kordzadze, A.A., 1989, "Matematicheskoe modelirovanie dinamiki morskikh techenij (teoriya, algoritmy, chislennye eksperimenty)”, Moscow, OVM AN SSSR, 218 p. (in Russian).

48. Zatsepin, A.G., Baranov, V.I. \& Kondrashov, A.A. [et al.], 2011, "Submesoscale eddies at the Caucasus Black Sea shelf and the mechanisms of their generation”, Oceanology, vol. 51, no. 4, pp. 554-567.

49. Ivanov, V.A., Tuchenkovenko, Yu.S., 2006, "Prikladnoe matematicheskoe modelirovanie kachestva vod shel'fovykh morskikh ekosistem [Applied mathematical modeling of water quality in sea shelf ecosystems]”, Sevastopol, MGI NAN Ukrainy, 368 p. (in Russian).

50. Demyshev, S.G., 2011, "Chislennyj prognosticheskij raschet techenij v Chernom more s vysokim gorizontal'nym razresheniem [Numerical prognostic calculation of currents in the Black Sea with a high horizontal resolution]”, Morskoj gidrofizicheskij zhurnal, no. 1, pp. 3647.

51. Oguz, T., Latun, V.S. \& Latif, M.A. [et al.], 1993, "Circulation in the surface and intermediate layers in the Black Sea”, Deep-Sea Res., no. 40, pp. 1597-1612.

52. Korotaev, G., Oguz, T. \& Nikiforov, A. [et al.], 2004, "Seasonal, interannual, and mesoscale variability of the Black Sea upper layer circulation derived from altimeter data", J. Geophys. Res., no. C4, doi: 10.1029/2002JC001508. 